JRKA Volume 4 Isue 2, Agustus 2018: 67 - 77

\title{
PENGARUH PERTUMBUHAN PERUSAHAAN, AUDIT TENURE DAN OPINI AUDIT TAHUN SEBELUMNYA TERHADAP OPINI AUDIT GOING CONCERN
}

\author{
Laras Pratiwi \\ Universitas Perjuangan \\ pratiwilaras.unper@gmail.com \\ Tri Hadrianto Lim \\ Universitas Parahyangan \\ tri_hadriantolim@yahoo.com
}

\begin{abstract}
The going concern audit opinion can used by stakeholders to predict the bankruptcy of a company, therefore the auditor should be responsible of his opinion. This study aims to obtain empirical evidence of the influence company growth, audit tenure and audit opinion of the previous year to going concern audit opinion. Population in this research using data manufacturing companies wich listed on the Indonesia Stock Exchange period 2013-2017. Method of Sampling is purposive sampling. Total sample are 22 companies. Research method using logistic regression analysis model. The results show that company's growth and the previous year's audit opinion affect to going concern audit opinion, while audit tenure doesn't affect to going concern audit opinion.

Keywords : Growth, Audit tenure, Going Concern Opinion
\end{abstract}

\begin{abstract}
Abstrak
Opini audit going concern dapat digunakan oleh para pemakai laporan keuangan sebagai prediksi kebangkrutan suatu perusahaan, oleh karena itu auditor harus mampu mempertanggungjawabkan hasil opininya. Penelitian ini bertujuan untuk memperoleh bukti empiris mengenai pengaruh pertumbuhan perusahaan, audit tenure dan opini audit tahun sebelumnya terhadap opini audit going concern. Populasi pada penelitian ini menggunakan data pada perusahaan manufaktur yang terdaftar di Bursa Efek Indonesia periode 2013-2017. Pengambilan sampel dilakukan dengan metode purposive sampling. Sampel yang diperoleh sebanyak 22 perusahaan. metode penelitian menggunakan model analisis regresi logistik. Hasil analisis menunjukan pertumbuhan perusahaan dan opini audit tahun sebelumnya berpengaruh terhadap opini audit going concern, sedangkan audit tenure tidak berpengaruh terhadap opini audit going concern.

Kata Kunci : pertumbuhan perusahaan, aaudit tenure, opini audit tahun sebelumnya, opini audit going concern.
\end{abstract}

\section{PENDAHULUAN}

Kelangsungan usaha disebut juga sebagai kontinuitas yang merupakan asumsi akuntansi yang memperkirakan suatu bisnis akan berlanjut dalam jangka waktu yang tidak terbatas (Syahrul dan Afdi, 2000). Kelangsungan usaha suatu perusahaan dapat diketahui melalui 
laporan audit berupa ada atau tidaknya opini audit going concern. Opini audit going concern merupakan opini yang dikeluarkan auditor untuk memastikan apakah perusahaan mampu mempertahankan kelangsungan hidupnya atau tidak (IAPI, 2011 : 341.1). Opini audit going concern digunakan oleh para pemakai laporan keuangan sebagai prediksi kebangkrutan suatu perusahaan. Opini atas kelayaan laporan keuangan suatu perusahaan diterbitkan oleh auditor pada Kantor Akuntan Publik (KAP). Oleh karena itu auditor harus mampu mempertanggungjawabkan hasil opininya. Masalah timbul ketika banyak terjadi kesalahan opini yang dibuat oleh auditor menyangkut opini going concern (Mayangsari, 2003). Misalnya pada kasus PT. Dwi Aneka Jaya Kemasindo. tahun 2014 perusahaan menerima opini audit wajar dengan pengecualian dari KAP Hadori, Sugiarto Adi \& Rekan, tetapi tahun 2015 KAP Hadori Sugiarto Adi \& Rekan menyatakan untuk memberikan opini tidak memberikan pendapat. Tahun 2016 perusahaan kembali menerima opini audit wajar dengan pengecualian tetapi pada 23 November 2017 perusahaan telah dinyatakan pailit oleh pengadilan niaga Jakarta Pusat. Perusahaan dinyatakan pailit karena tidak mampu membayar utang kepada beberapa bank, akhirnya Mei 2018 perusahaan di-delisting dari Bursa Efek Indonesia (Sugianto, 2018). Kondisi ini membuktikan bahwa perusahaan dengan opini wajar tidak selalu memberikan jaminan bahwa perusahaan mampu mempertahankan kelangsungan usahanya, sehingga seorang investor perlu memiliki ketelitian dan analisis yang mendalam mengenai adanya opini audit going concern.

Perusahaan mampu memberikan return yang tinggi kepada investor jika memiliki prospek yang baik. Prospek perusahaan dapat tergambar salah satunya melalui pertumbuhan perusahaan. Altman (1968) mengemukakan bahwa perusahaan yang terus-menerus mencetak laba tidak akan mengalami kebangkrutan, artinya apabila perusahaan terus-menerus mencetak laba maka potensi perusahaan untuk menerima opini audit going concern sangat kecil, karena perusahaan dinilai mampu untuk mempertahankan kelangsungan usahanya. Hal ini berbeda dengan perusahaan yang memiliki negative growth. Perusahaan dengan negative growth mengindikasikan kecenderungan yang lebih besar mengalami kebangkrutan dan tidak mampu menjamin kelangsungan usahanya. Hal ini sejalan dengan penelitian yang dilakukan oleh Ginting dan Suryana (2014) serta Kartika (2012) yang menyatakan bahwa pertumbuhan perusahaan berpengaruh terhadap opini audit going concern. Namun hal tersebut tidak sesuai dengan penelitian yang dilakukan oleh Santosa dan Wedari (2007) yang menyatakan bahwa pertumbuhan perusahaan tidak berpengaruh terhadap opini audit going concern.

Seorang auditor harus memiliki sikap independen dalam mengaudit laporan keuangan suatu perusahaan, agar opini yang terbitkan mampu dipertanggungjawabkan. Independensi salah satunya dapat diukur melalui audit tenure. Audit tenure adalah lama hubungan atau keterikatan antara auditor dengan kliennya. Semakin lama hubungan klien dengan auditor dikhawatirkan akan mempengaruhi tingkat independensi auditor dalam memberikan pendapatnya. Ketika auditor telah berhubungan bertahun-tahun dengan klien, klien dipandang sebagai sumber penghasilan untuk auditor yang secara potensial dapat mengurangi independensi (Yuvisa, dkk, 
2008). Hal ini sesuai dengan penelitian yang dilakukan oleh Arsianto dan Rahardjo (2013) yang menyatakan bahwa audit tenure berpengaruh terhadap opini audit going concern. Namun tidak sesuai dengan penelitian yang dilakukan oleh Januarti \& Fitrianasari (2008) yang menyatakan bahwa audit tenure tidak berpengaruh terhadap opini audit going concern. Faktor lain yang mempengaruhi opini audit going concern adalah opini audit tahun sebelumnya. Opini yang didapatkan dari tahun sebelumnya akan mempengaruhi kelangsungan usahanya. Perusahaan yang mendapatkan opini audit going concern pada tahun sebelumnya, memiliki kecenderungan mengalami permasalahan baru di tahun berjalan. Hal tersebut semakin mempersulit pihak manajemen untuk mempertahankan kelangsungan hidupnya. Mengingat masih adanya ketidakkonsistenan dari penelitianpenelitian sebelumnya, maka berdasarkan latar belakang yang telah diuraikan diatas, penelitian ini bermaksud menguji kembali sejauhmana pengaruh pertumbuhan perusahaan, audit tenure, dan opini audit tahun sebelumnya terhadap opini audit going concern.

\section{KAJIAN TEORITID DAN HIPOTESIS}

\section{Opini Audit Going concern}

Opini audit going concern merupakan opini audit modifikasi yang diberikan auditor bila terdapat keraguan atas kelangsungan usaha suatu perusahaan. Standar Audit seksi 341 paragraf 2 menjelaskan bahwa auditor bertanggung jawab untuk mengevaluasi apakah terdapat kesangsian besar terhadap kemampuan entitas dalam mempertahankan kelangsungan hidupnya dalam periode waktu pantas, tidak lebih dari satu tahun sejak tanggal laporan keuangan yang sedang diaudit (IAPI, 2011). Opini audit going concern dalam penelitian ini diproksi melalui variabel dummy.

\section{Pertumbuhan Perusahaan}

Definisi growth menurut Fahmi (2014:82) adalah rasio yang mengukur seberapa besar kemampuan perusahaan dalam mempertahankan posisinya di dalam industri dan dalam perkembangan ekonomi secara umum. Penjualan merupakan kegiatan operasi utama perusahaan. Penjualan perusahaan yang meningkat dari tahun ke tahun memberi peluang perusahaan untuk memperoleh peningkatan laba. Oleh karena itu, semakin tinggi rasio pertumbuhan penjualan perusahaan akan semakin kecil kemungkinan auditor untuk menerbitkan opini audit going concern (Setyarno, dkk : 2006). Pertumbuhan perusahaan dalam penelitian ini diukur melalui sales growth.

\section{Audit tenure}

Audit tenure merupakan jangka waktu perikatan yang terjalin antara Kantor Akuntan Publik (KAP) dengan auditee yang sama. Tahun 2017 muncul peraturan terkait pembatasan jasa audit yang diatur dalam Peraturan Otoritas Jasa Keuangan Nomor 13/POJK.03/2017 pasal 16 ayat 1 tentang Penggunaan Jasa Akuntan Publik dan Kantor Akuntan Publik dalam Kegiatan Jasa Keuangan menyatakan bahwa pihak yang melaksanakan kegiatan jasa keuangan wajib membatasi penggunaan jasa audit atas informasi keuangan historis tahunan dari akuntan publik yang sama paling lama untuk periode audit selama 3 (tiga) tahun buku pelaporan secara berturut-turut. 


\section{Opini Audit Tahun Sebelumnya}

Opini audit tahun sebelumnya adalah opini audit yang diterima auditee pada tahun sebelumnya atau satu tahun sebelum tahun berjalan. Mutchler (1984) melakukan wawancara dengan praktisi auditor yang menyatakan bahwa perusahaan yang menerima opini audit going concern pada tahun sebelumnya lebih cenderung untuk menerima opini yang sama pada tahun berjalan. Apabila auditor mengeluarkan opini audit going concern pada tahun sebelumnya, maka semakin besar kemungkinan auditor mengeluarkan opini audit going concern pada tahun berjalan. Opini audit going concern pada penelitian ini diukur melalui variabel dummy.

\section{Pertumbuhan Perusahaan terhadap Opini Audit Going concern}

Pertumbuhan

perusahaan menunjukkan kekuatan perusahaan dalam industri dan mengindikasikan kemampuan perusahaan untuk mempertahankan kelangsungan usahanya (Rudyawan \& Badera : 2009). Perusahaan yang mengalami pertumbuhan menunjukkan aktivitas operasional yang positif, artinya perusahaan berjalan dengan semestinya sehingga perusahaan dapat mempertahankan posisi ekonomi dan kelangsungan hidupnya. Sedangkan perusahaan dengan negative growth mengindikasikan kecenderungan yang lebih besar ke arah kebangkrutan (Altman, 1968). Hal ini didukung oleh beberapa penelitian terdahulu yaitu Kartika (2012), Ginting \& Suryana (2014) serta Nursasi \& Maria (2015) yang menyatakan bahwa pertumbuhan perusahaan berpengaruh terhadap opini audit going concern.
$\mathrm{H}_{1}$ : Diduga pertumbuhan perusahaan berpengaruh terhadap opini audit going concern.

\section{Audit tenure terhadap Opini Audit Going concern.}

Opini audit going concern juga tidak terlepas dari independensi auditor. Menurut SPAP (2011 : 220) auditor dianggap bersikap independen apabila tidak mudah dipengaruhi. Auditor melaksanakan pekerjaan demi kepentingan umum sehingga auditor tidak dibenarkan untuk memihak kepentingan kepada siapapun. Wooten (2003) menjelaskan bahwa semakin lama hubungan auditor dengan kliennya maka akan mengganggu independensi. Audit tenure merupakan periode waktu perikatan antara Kantor Akuntan Publik (KAP) dan perusahaan klien yang sama. Kekeliruan dalam memberikan opini audit banyak terjadi pada masa kerja yang pendek atau terlalu lama. Hubungan auditor dengan perusahaan klien yang cukup lama berpotensi menjadikan auditor merasa puas pada apa yang dilakukan seperti melakukan audit yang kurang tegas dan terlalu tergantung pada pernyataan manajemen (Deis \& Giroux, 1992). Hal ini didukung oleh penelitian Arsianto dan Rahardjo (2013) dan Nursasi dan Maria (2015) yang menyatakan bahwa audit tenure berpengaruh terhadap opini audit going concern.

$\mathrm{H}_{2}$ : Diduga audit tenure berpengaruh terhadap opini audit going concern.

\section{Opini Audit Tahun Sebelumnya terhadap Opini Audit Going concern}

Auditee yang menerima opini going concern pada tahun sebelumnya dianggap memiliki masalah dalam mempertahankan 
kelangsungan usahanya, sehingga semakin besar kemungkinan bagi auditor untuk mengeluarkan opini audit going concern pada tahun berjalan (Setyarno, dkk : 2006). Perusahaan yang mendapatkan opini audit going concern pada tahun sebelumnya memiliki kecenderungan untuk mengalami permasalahan baru di tahun berjalan, seperti hilangnya kepercayaan publik, sehingga akhirnya akan semakin mempersulit manajemen perusahaan untuk mempertahankan kelangsungan hidupnya. Jika perusahaan tidak berhasil menunjukkan peningkatan signifikan di tahun berjalan dibandingkan dengan tahun sebelumnya, maka perusahaan akan mendapatkan opini audit going concern kembali (Kartika : 2012). Hal ini didukung oleh penelitian Santosa dan Wedari (2007), Kartika (2012), serta Syarifah dan Kurnia (2017) yang menyatakan bawa opini audit tahun sebelumnya berpengaruh terhadap opini audit going concern.

$\mathrm{H}_{3}$ : Diduga opini audit tahun sebelumnya berpengaruh terhadap opini audit going concern.

Berdasarkan penjelasan diatas maka dapat dibangun model penelitian sebagai berikut ini:

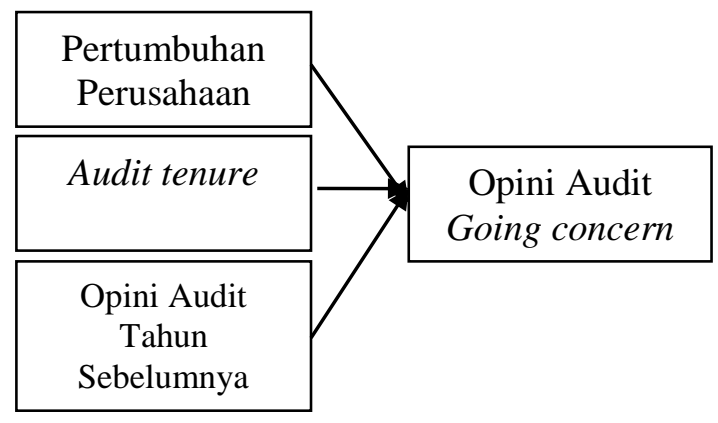

Gambar 2.1. Model Penelitian

\section{METODOLOGI}

\section{Jenis Penelitian dan Objek Penelitian}

Penelitian ini berbentuk penelitian asosiatif dengan menggunakan pendekatan kuantitatif yang bertujuan untuk mengetahui hubungan variabel pertumbuhan perusahaan, audit tenure, dan opini audit tahun sebelumnya terhadap opini audit going concern.

\section{Jenis dan Sumber Data}

Data yang digunakan dalam penelitian ini adalah data sekunder. Sumber data yang digunakan dalam penelitian ini adalah laporan tahunan perusahaan sektor manufaktur yang diperoleh melalui website Bursa Efek Indonesia.

\section{Teknik Analisis Data.}

Analisis data dalam penelitian ini menggunakan regresi logistik. Menurut Ghozali (2013 : 225) analisis regresi logistik digunakan untuk memprediksi variabel terikat berdasarkan variabel bebasnya. Penelitian ini memiliki variabel terikat opini audit going concern yang merupakan variabel dummy. Regresi logistik digunakan untuk menguji apakah probabilitas terjadinya variabel terikat dapat diprediksi dengan variabel bebasnya.

\section{HASIL DAN PEMBAHASAN Analisis Regresi Logistik}

\section{Uji Multikolinearitas}

Uji multikolinearitas bertujuan untuk menguji apakah model regresi ditemukan adanya korelasi antar variabel bebas. Uji multikolinearitas dapat diukur melalui nilai VIF (Variance Inflating Factor). Apabila 
nilai VIF melebihi angka 10 maka dapat dikatakan terdapat multikolinearitas dalam model. Adapun hasil dari uji multikolinearitas dalam penelitian ini adalah sebagai berikut :

Tabel 4.1.

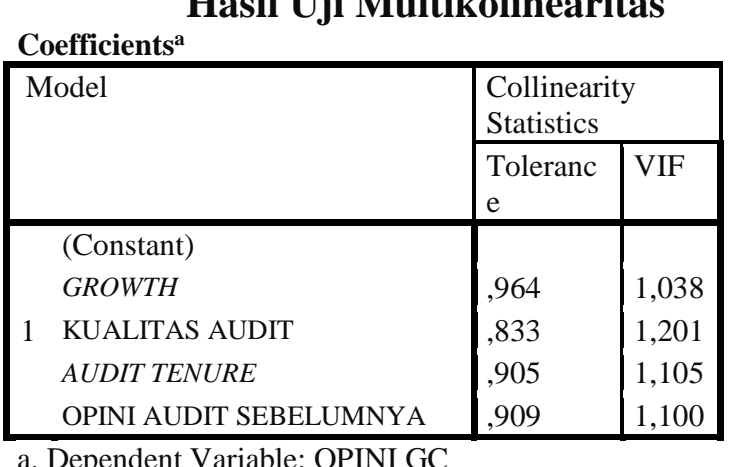

Sumber : Output SPSS 20.0

Berdasarkan Tabel 4.1. dapat dilihat bahwa semua variabel memiliki nilai tolerance yang lebih besar dari 0,1 dan nilai VIF untuk semua variabel independen memiliki nilai lebih kecil dari 10. Dengan demikian dapat disimpulkan bahwa tidak terdapat multikolinearitas antar variabel dalam model regresi.

\section{Uji Keseluruhan Model (Overall Model Fit).}

Pengujian yang digunakan untuk menilai fit-nya suatu model dalam penelitian ini yang pertama adalah melalui uji Likelihood Ratio Test. Adapun hasil uji keseluruhan model pada penelitian ini adalah sebagai berikut :
Tabel 4.2.

\section{Hasil Uji Keseluruhan Model Fit} (Overall Model Fit) Block $=0$

Iteration History $\mathbf{a}, \mathbf{b}, \mathbf{c}$

\begin{tabular}{|ll|l|l|}
\hline \multicolumn{2}{|l|}{ Iteration } & -2 Log likelihood & Coefficients \\
\cline { 4 - 4 } & 1 & 105,230 & Constant \\
\hline \multirow{3}{*}{ Step 0 } & 2 & 104,314 & $-1,273$ \\
& 3 & 104,311 & $-1,489$ \\
& 4 & 104,311 & $-1,504$ \\
& 4 & & $-1,504$ \\
\hline
\end{tabular}

a. Constant is included in the model.

b. Initial -2 Log Likelihood: 104,311

c. Estimation terminated at iteration number 4 because parameter estimates changed by less than ,001.

Sumber : Output SPSS 20.0

Tabel 4.3.

\section{Uji Keseluruhan Model Fit (Overall Model Fit) Block = 1}

Iteration History ${ }^{\mathrm{a}, \mathrm{b}, \mathrm{c}, \mathrm{d}}$

\begin{tabular}{|c|c|c|c|c|c|c|c|}
\hline \multirow{2}{*}{\multicolumn{2}{|c|}{$\begin{array}{l}\text { Iteratio } \\
n\end{array}$}} & \multirow{2}{*}{$\begin{array}{l}-2 \text { Log } \\
\text { likeliho } \\
\text { od }\end{array}$} & \multicolumn{5}{|c|}{ Coefficients } \\
\hline & & & $\begin{array}{l}\text { Const } \\
\text { ant }\end{array}$ & $\mathrm{X} 1$ & $\mathrm{X} 2$ & X3 & $\mathrm{X} 4$ \\
\hline \multirow{7}{*}{$\begin{array}{l}\text { Step } \\
1\end{array}$} & 1 & 61,046 & $-1,798$ &, 023 &,- 256 & ,023 & 2,946 \\
\hline & 2 & 52,125 & $-2,556$ &, 048 &,- 685 & ,059 & 3,810 \\
\hline & 3 & 50,538 & $-2,925$ &, 064 & $-1,266$ & ,099 & 4,119 \\
\hline & 4 & 50,364 & $-3,044$ & ,069 & $-1,631$ &, 121 & 4,212 \\
\hline & 5 & 50,361 & $-3,061$ & ,070 & $-1,700$ & , 125 & 4,226 \\
\hline & 6 & 50,361 & $-3,062$ &, 070 & $-1,702$ & , 125 & 4,226 \\
\hline & 7 & 50,361 & $-3,062$ &, 070 & $-1,702$ & , 125 & 4,226 \\
\hline \multicolumn{8}{|c|}{$\begin{array}{l}\text { a. Method: Enter } \\
\text { b. Constant is included in the model. } \\
\text { c. Initial -2 Log Likelihood: } 104,311\end{array}$} \\
\hline
\end{tabular}

Sumber : Output SPSS 20.0

Berdasarkan Tabel 4.2. dan Tabel 4.3. dapat dilihat bahwa nilai -2 Log Likelihood awal (block number $=0$ ) adalah 105,230 dan nilai -2 Log Likelihood akhir (block number = 1) menjadi 61,046 hasil ini menunjukan penurunan nilai $-2 \quad$ Log Likelihood yang signifikan sehingga dapat diartikan bahwa model regresi yang dihipotesiskan sudah fit dengan data yang ada. 
Uji Kelayakan Model (Hosmer and Lemeshow Test)

Hosmer and Lemeshow's Goodness of Fit Test (uji kelayakan model regresi) dilakukan untuk menguji hipotesis nol bahwa data empiris cocok atau sesuai dengan model regresi. Kelayakan model regresi dinilai dengan menggunakan Hosmer and Lemeshow's Goodness of Fit Test. Jika nilai statistik Hosmer and Lemeshow Goodness of Fit Test lebih besar daripada 0,05 berarti model mampu mampu memprediksi nilai observasinya atau dapat dikatakan model dapat diterima karena sesuai dengan data observasinya. Adapun hasil dari Uji Kelayakan Model (Hosmer and Lemeshow Test) pada penelitian ini adalah sebagai berikut :

Tabel 4.4.

Hasil Uji Kelayakan Model Hosmer and Lemeshow Test

\begin{tabular}{|l|l|l|l|}
\hline Step & Chi-square & Df & Sig. \\
\hline 1 & 9,238 & 7 &, 236 \\
\hline
\end{tabular}

Sumber : Output SPSS 20.0

Berdasarkan Tabel 4.4. terlihat bahwa nilai Hosmer and Lemeshow's Goodness of Fit Test sebesar 0,236 lebih besar dari nilai signifikansi 0,05 dengan tingkat keyakinan 95\% maka dapat dikatakan bahwa model regresi yang digunakan pada penelitian ini mampu menjelaskan data.

\section{Uji Koefisien Determinasi (Nagelkerke R. Square).}

Uji koefisien determinasi dengan menggunakan Nagelkerke $R$ Square merupakan pengujian yang dilakukan untuk mengetahui seberapa besar variabel independen mampu menjelaskan dan mempengaruhi variabel dependen. Adapun hasil Uji Koefisien Determinasi
(Nagelkerke R. Square) dalam penelitian ini adalah sebagai berikut :

Tabel 4.5.

\section{Hasil Uji Koefisien Determinasi} (Nagelkerke R. Square)

Model Summary

\begin{tabular}{|l|l|lr|l|}
\hline Step & $\begin{array}{l}-2 \quad \text { Log } \\
\text { likelihood }\end{array}$ & $\begin{array}{l}\text { Cox } \\
\text { Snell } \\
\text { Square }\end{array}$ & $\begin{array}{l}\text { Nagelkerke R } \\
\text { Square }\end{array}$ \\
\hline 1 & $50,361^{\mathrm{a}}$ &, 388 &, 633 \\
\hline
\end{tabular}

a. Estimation terminated at iteration number 7 because parameter estimates changed by less than ,001.

Sumber : Output SPSS 20.0

Berdasarkan Tabel 4.5. dapat dilihat bahwa nilai Nagelkerke $R$ Square pada penelitian ini adalah sebesar 0,633. Hal ini berarti bahwa $63,3 \%$ variasi atau perubahan dalam opini audit going concern dapat dijelaskan oleh variasi pertumbuhan penjualan, audit tenure, dan opini audit tahun sebelumnya. Sedangkan sisanya $36,7 \%$ dijelaskan oleh sebab-sebab lain yang tidak dimasukkan dalam model penelitian.

\section{Pengujian Hipotesis}

\section{Uji Hipotesis Parsial - Uji Wald}

Pengujian hipotesis dalam regresi logistik menggunakan uji Wald. Uji Wald digunakan untuk menguji ada atau tidaknya pengaruh dari variabel bebas terhadap variabel terikatnya secara parsial. Berdasarkan model regresi yang telah dibangun untuk menguji hipotesis ini adalah sebagai berikut : 
Tabel 4.6.

Hasil Uji Hipotesis Parsial - Uji Wald

Variables in the Equation

\begin{tabular}{|ll|l|l|l|l|l|}
\hline & & B & S.E. & Wald & Df & Sig. \\
\hline & X1 &, 070 &, 143 &, 240 & 1 &, 025 \\
St & X2 &, 125 &, 265 &, 223 & 1 &, 637 \\
ep & X3 & 4,226 &, 786 & 28,916 & 1 &, 000 \\
$1^{\text {a }}$ & Const \\
& ant & $-3,062$ &, 928 & 10,897 & 1 &, 001 \\
\hline
\end{tabular}

a. Variable(s) entered on step 1: X1, X2, X3 .

Sumber : Output SPSS 20.0

Berdasarkan Tabel 4.6. tersebut rincian mengenai pengaruh masing-masing variabel bebas terhadap variabel terikatnya dapat dijelaskan sebagai berikut ini :

1. Variabel pertumbuhan perusahaan $\left(\mathrm{X}_{1}\right)$ memiliki nilai signifikansi 0,025 lebih kecil dari $0,05(0,025<0,05)$. $\mathrm{Hal}$ ini menunjukan bahwa $\mathrm{H}_{\mathrm{a} 1}$ diterima yaitu pertumbuhan perusahaan $\left(\mathrm{X}_{1}\right)$ berpengaruh terhadap opini audit going concern (Y).

2. Variabel audit tenure $\left(\mathrm{X}_{3}\right)$ memiliki nilai signifikansi 0,637 lebih besar dari $0,05(0,637>0,05)$. Hal ini menunjukan bahwa $\mathrm{H}_{03}$ diterima yaitu audit tenure $\left(\mathrm{X}_{3}\right)$ tidak berpengaruh terhadap opini audit going concern (Y).

3. Variabel opini audit tahun sebelumnya $\left(\mathrm{X}_{4}\right)$ memiliki nilai signifikansi 0,000 lebih kecil dari 0,05 (0,000<0,05). $\mathrm{Hal}$ ini menunjukan bahwa $\mathrm{H}_{\mathrm{a} 4}$ diterima yaitu opini audit tahun sebelumnya $\left(\mathrm{X}_{4}\right)$ berpengaruh terhadap opini audit going concern (Y).

\section{Pembahasan Hasil Penelitian. \\ Pengaruh Pertumbuhan Perusahaan (X) terhadap Opini Audit Going concern (Y)}

Berdasarkan Tabel 4.6. variabel pertumbuhan perusahaan $\left(\mathrm{X}_{1}\right)$ memiliki nilai signifikansi 0,025 lebih kecil dari $0,05(0,025<0,05)$. Hal ini menunjukkan bahwa $\mathrm{H}_{\mathrm{a} 1}$ diterima yaitu pertumbuhan perusahaan $\left(\mathrm{X}_{1}\right)$ berpengaruh terhadap opini audit going concern (Y). Pertumbuhan perusahaan mampu menggambarkan kemampuan perusahaan dalam mempertahankan kegiatan operasional perusahaannya. Pertumbuhan perusahaan dalam penelitian ini diukur melalui sales growth. Penjualan merupakan kegiatan utama perusahaan, sehingga apabila penjualan meningkat dari tahun ke tahun maka perusahaan dinilai memiliki prospek yang baik di masa yang akan datang. Nilai penjualan yang terus bertumbuh, selain menjamin kegiatan operasional perusahaan juga akan menghasilkan laba yang tinggi. Jumlah laba yang tinggi mampu menyediakan sumber dana bagi perusahaan untuk menjaga keberlangsungan usahanya dan mendukung perusahaan dalam melakukan perluasan usaha. Altman (1968) mengemukakan bahwa perusahaan yang terus-menerus mengalami peningkatan laba cenderung tidak akan mengalami kebangkrutan, artinya apabila perusahaan terus-menerus mendapat laba maka potensi perusahaan untuk menerima opini audit going concern sangat kecil, karena perusahaan dinilai mampu untuk mempertahankan kelangsungan usahanya. Berbeda dengan perusahaan yang memiliki negative growth, perusahaan dengan negative growth mengindikasikan kecenderungan yang lebih besar mengalami kebangkrutan dan tidak mampu menjamin kelangsungan usahanya. Kondisi perusahaan dengan positive sales growth memberikan keyakinan kepada auditor bahwa perusahaan mampu menjaga eksistensinya, sedangkan perusahaan yang memiliki negative sales growth menimbulkan kesangsian pada auditor 
mengenai apakah perusahaan mampu menjaga kelangsungan usahanya atau tidak. Kesangsian ini pada akhirnya yang menyebabkan auditor memberikan opini audit going concern. Hal ini sejalan dengan penelitian yang dilakukan oleh Kartika (2012), Setyarno, dkk (2016), serta Nursasi dan Maria (2015) yang menyatakan bahwa pertumbuhan perusahaan berpengaruh terhadap opini audit going concern.

\section{Pengaruh Audit tenure $\left(\mathrm{X}_{2}\right)$ terhadap Opini Audit Going concern (Y).}

Berdasarkan Tabel 4.6. variabel audit tenure $\left(\mathrm{X}_{3}\right)$ memiliki nilai signifikansi 0,637 lebih besar dari 0,05 $(0,637>0,05)$. Hal ini menunjukkan bahwa $\mathrm{H}_{03}$ diterima bahwa audit tenure $\left(\mathrm{X}_{3}\right)$ tidak berpengaruh terhadap opini audit going concern (Y). Lamanya perikatan audit yang dilakukan oleh perusahaan dengan KAP dikhawatirkan akan mengganggu independensi. Tetapi berdasarkan bukti empiris penelitian ini lamanya perikatan audit tidak terbukti akan memberikan gangguan pada tingkat independensi auditor. Seorang auditor cenderung menjaga nama baiknya serta KAP tempat auditor tersebut bekerja, karena jika auditor bersifat tidak independen maka reputasi akan hancur dan tidak ada lagi yang mempercayai KAP tersebut. Maka dari itu, seorang auditor dituntut untuk memiliki independence in fact dan independence in appereance. Seorang auditor wajib menjaga nama baiknya serta nama baik KAP-nya dengan memiliki kejujuran yang tinggi, bersifat objektif, sehingga pihak lain berpandangan positif terhadap diri auditor dan KAP sehubungan dengan pelaksanaan auditnya. Hal ini sejalan dengan penelitian yang dilakukan oleh Verdiana dan Utama
(2013) yang menyatakan bahwa audit tenure tidak berpengaruh terhadap opini going concern.

\section{Pengaruh Opini Audit Tahun Sebelumnya $\left(\mathrm{X}_{3}\right)$ terhadap Opini Audit Going concern (Y)}

Berdasarkan Tabel 4.6. variabel opini audit tahun sebelumnya $\left(\mathrm{X}_{4}\right)$ memiliki nilai signifikansi 0,000 lebih kecil dari $0,05(0,000<0,05)$. Hal ini menunjukkan bahwa $\mathrm{H}_{\mathrm{a} 4}$ diterima yaitu opini audit tahun sebelumnya $\left(\mathrm{X}_{4}\right)$ berpengaruh terhadap opini audit going concern (Y). Apabila perusahaan menerima opini audit going concern pada tahun sebelumnya maka akan menjadi pertimbangan bagi auditor dalam memberikan opini yang sama di tahun berjalan. Auditor perlu meyakini apakan kondisi perusahaan di tahun berjalan sudah lebih baik dari tahun sebelumnya atau masih sama, sehingga opini audit tahun sebelumnya menjadi hal yang penting untuk dipertimbangkan. Apabila perusahaan mampu meningkatkan performanya di tahun berjalan maka besar kemungkinan perusahaan tidak mendapatkan opini audit going concern, namun jika perusahaan tidak mampu meningkatkan performanya maka besar juga kemungkinan perusahaan menerima kembali opini audit going concern seperti tahun sebelumnya.

\section{KESIMPULAN DAN SARAN Kesimpulan}

Berdasarkan hasil penelitian dan analisis data yang telah dilakukan untuk mengetahui pengaruh pertumbuhan perusahaan, kualitas audit, audit tenure, dan opini audit tahun sebelumnya terhadap opini audit going concern maka dapat disimpulkan beberapa hal berikut ini 
1. Pertumbuhan perusahaan berpengaruh terhadap opini audit going concern.

2. Audit tenure berpengaruh terhadap opini audit going concern.

3. Opini audit tahun sebelumnya berpengaruh terhadap opini audit going concern.

\section{Saran}

Berdasarkan hasil penelitian ini, peneliti memberikan beberapa saran sebagai berikut:

1. Bagi perusahaan emiten hendaknya selalu mempertahankan

keberlangsungan usahanya, salah satunya melalui peningkatan penjualan. Peningkatan penjualan mampu memberikan keyakinan bahwa perusahaan dapan terus menjalankan kegiatan usahanya. Di samping itu, peningkatan penjualan secara terusmenerus juga memberikan keyakinan kepada masyarakat bahwa perusahaan memiliki prospek yang baik di masa yang akan datang.

2. Bagi investor, hendaknya lebih objektif dalam memilih perusahaan untuk berinvestasi. Perusahaan dengan opini audit going concern berarti memiliki kesangsian untuk tetap menjalankan usahanya di masa yang akan datang. Oleh sebab itu investor harus teliti dalam memilih perusahaan untuk dijadikan tempat berinvestasi.

3. Bagi auditor, hendaknya selalu mempertahankan independensi dan keobjektifan dalam melakukan audit bagi suatu perusahaan sehingga opini audit yang diberikan sesuai dengan kondisi keuangan perusahaan yang sebenarnya. Hal ini tentu akan sangat berguna bagi para pengguna laporan keuangan untuk mengambil keputusan.

4. Bagi peneliti selanjutnya, sebaiknya menambahkan variabel yang lain seperti ukuran perusahaan, kinerja keuangan, maupun variabel nonkeuangan agar dapat diketahui faktorfaktor apa saja yang mempengaruhi opini audit going concern. Apabila melakukan penelitian yang serupa, periode pengamatan diharapkan lebih panjang. Selain itu, penelitian selanjutnya dapat diperluas tidak hanya di perusahaan sektor manufaktur saja melainkan juga sektor lainnya.

\section{DAFTAR PUSTAKA}

Altman, E. I. (1968). Financial Ratios, Discriminant Analysis and The Prediction of Corporate Bankruptcy. The Journal of Finance Vol.XXIII No.4, 589-609.

Arsianto, M. R., \& Rahardjo, S. N. (2013). Faktor-Faktor yang Mempengaruhi Penerimaan Opini Audit Going Concern. Diponegoro Journal of Accounting, 1.

Deis, D., \& Giroux, G. (1992). Determinants of Audit Quality in the Public Sector. The Accounting Review Vol.67 No.3, 462-479.

Fahmi, I. (2014). Analisis Laporan Keuangan. Bandung: Alfabeta.

Ghozali, I. (2013). Aplikasi Analisis Multivariate dengan Program IBM SPSS 21 Update PLS Regresi. Semarang: Badan Penerbit Universitas Diponegoro.

Ginting, Suriani dan Linda Suryana. 2014. Analisis Faktor-Faktor yang Mempengaruhi Opini Audit Going Concern pada Perusahaan Manufaktur di Bursa Efek Indonesia. Jurnal Wira Ekonomi Mikroskis. Vol. 4, No. 2, Hal 111-120.

Institut Akuntan Publik Indonesia (IAPI). (2011). Standar Profesional Akuntan Publik. Jakarta: Salemba Empat 
Januarti, I., \& Fitrianasari, E. (2008). Analisis Rasio Keuangan dan Rasio Non Keuangan yang Mempengaruhi Auditor dalam Memberikan Opini Audit Going Concern pada Auditee (Studi Empiris pada Perusahaan Manufaktur yang Terdaftar di BEJ Tahun 2000-2005). Jurnal Maksi Vol.8 No.1, 43-58.

Kartika, A. (2012). Pengaruh Kondisi Keuangan dan Non Keuangan terhadap Penerimaan Dinamika Akuntansi, Keuangan dan Perbankan Vol.1 No.1, 25-40.

Mayangsari, S. 2003. Pengaruh Kualitas Audit dan Independensi terhadap Integritas Laporan Keuangan. Simposium Nasional Akuntansi VI.

Mutchler, J. F. (1984). Auditors' Perception of The Going-Concern Opinion Decision. Auditing: A Journal of Practice and Theory. Vol. 3, No. 2, 17-30.

Nursasi, E., \& Maria, E. (2015). Pengaruh Audit tenure, Opinion Shopping, Leverage Dan Pertumbuhan Perusahaan Terhadap Penerimaan Opini Audit Going Concern Pada Perusahaan Perbankan Dan Pembiayaan Yang Go Public Di Bursa Efek Indonesia. Jurnal JIBEKA Vol.9 No.1.

Otoritas Jasa Keuangan. 2017. Peraturan Otoritas Jasa Keuangan No: 13/POJK.03/2017 Penggunaan Jasa Akuntan Publik dan Kantor Akuntan Publik dalam Kegiatan Jasa Keuangan.

Rudyawan, A. P., \& Badera, I. D. (2009). Opini Audit Going Concern: Kajian Berdasarkan Model Prediksi Kebangkrutan, Pertumbuhan Perusahaan, Leverage, dan Reputasi Auditor. Jurnal Akuntansi dan Bisnis Vol.4 No.2, 1-17.
Santosa, A. F., \& Wedari, L. K. (Desember 2007). Analisis Faktor-Faktor yang Mempengaruhi Kecenderungan Penerimaan Opini Audit Going Concern. JAAI Vol 11, 141-158.

Setyarno, Budi, E., Januarti, I., \& Faisal. (2006). Pengaruh Kualitas Audit, Kondisi Keuangan Perusahaan, Opini Audit Tahun Sebelumnya. Simposium Nasional Akuntansi IX. Vol 9, 1-25.

Sugianto, D. (2018, Mei 22). Dwi Aneka Jaya Kemasindo Didepak dari Bursa Saham. Retrieved Juli 20, 2018, from https://finance.detik.com/bursa-danvalas/d-4032340/dwi-aneka-jayakemasindo-didepak-dari-bursa-saham Syahrul, \& Afdi, M. (2000). Kamus Akuntansi. Jakarta: Citra Harta Prima. Syarifah, A. N., \& Kurnia. (2017). Pengaruh Faktor Keuangan dan Non Keuangan terhadap Pemberian Opini Audit Going concern. Jurnal Ilmu dan Riset Akuntansi Vol.6 No.5, 20322050.

Verdiana Komang Anggita dan I Made Karya Utama. 2013. "Pengaruh Reputasi Auditor, Disclosure, Audit Client Tenure pada Kemungkinan Pengungkapan Opini Audit Going Concern". E-Jurnal Akuntansi Universitas Udayana 5.3 (2013):530543.

Wooten, T.G. 2003. It is Impossible to Know The Number of Poor-Quality Audits that simply go undetected and unpublicized. The CPA Journal. Januari. p. 48-51.

Yuvisa, Ewing, Abdul Rohman dan $\mathrm{Hj}$. Rr Sri Handayani. 2005. Pengaruh Identifikasi Auditor atas Klien Terhadap Objektivitas Auditor dengan Auditor Tenure, Client Importance dan Client Image sebagai Variabel anteseden. 